\title{
The analysis of various measures of the speed control of the traffic in the cities and settlements of the Republic of Belarus
}

\section{Denis Kapski ${ }^{\mathbb{D}}$, Antonina Korzhova}

Belarusian National Technical University, Independence av., 65, Minsk, 220013, Belarus

* Dr, Professor, Dean of Automotive and Tractor Faculty, Senior Project Engineer

** MCs, Researcher, Scientific-Research Center of Traffic

\section{open $(2$ access (cc) dol}

\section{Article history:}

Received: September 12, 2017

1st Revision: October 10, 2017

Accepted: October 28, 2017

\section{DOI:}

10.14254/jsdtl.2017.2-2.2

\begin{abstract}
The results of the analysis of various measures of calm of movement in cities and settlements are presented in the article. The alternative measures of physical and psychological effects on the traffic participants are considered. Particular attention is paid to the application of speed humps. They are installed on the streets of cities and settlements widely. The statistics of road traffic accidents at sites with humps in Minsk are considered. Various aspects of the effect of speed humps on accident rate have been established. And experimental studies of the instantaneous speeds of road vehicles in the installation area of speed humps have been performed. New modifications of speed humps are proposed, the design of which was developed on the basis of research of interactions with the car. Also the study investigated the effect of hump on the accident rate, delays in transportation, changes of speed and flow density. In addition, specific proposals have been developed. They are included in the technical normative legal acts in our country partially. That proposals allows to increase the overall quality of traffic (minimize the total economic, environmental and emergency losses from installation of speed humps). For example, alternative variants of design decisions on improvement of quality traffic safety are considered. In addition, the article considers other measures of forced speed control on streets network of cities and settlements in the country.
\end{abstract}

Keywords: Road traffic, road safety, quality, forced speed limit, speed control, physical and psychological impact traffic measures, traffic accidents, speed humps. 


\section{Introduction}

The traffic calming is one of basic approaches for traffic safety on city streets and it is based on the concept of speed control. The purpose of such approach is minimization of the passing transit flows through region streets, the pedestrians and cyclists safety and influence on the drivers' behavior in city conditions.

City streets shall be designed taking into account restriction of "excess" speed and also according to category and assignment. It is necessary to consider the functional capabilities of the street, the homogeneity of traffic flow, the relevance of the introduced restrictions, the predictability of the used technical means of the organization of traffic (Preston, 2006).

The main criteria can be:

- the accident rate (on the researched section of the street focuses of the accident rate with a high traffic speed are considered);

- the speed (exceeding of the authorized speed more than on $10 \mathrm{~km} / \mathrm{h}$ of mostly moving vehicles (according to the European approaches more than 15\% of all flow));

- the open-end traffic (the functional purpose of the street, the character of the apartment block, closeness of objects of an pedestrians attraction (schools, policlinics, parks, etc.) is considered);

- specific traffic conditions (for example, a gateway on the main street).

\section{Literature review}

The term "traffic calming" is understood as forced reduction the cars speeds (Räsänen, 2005; Jaeger, 2008; Maine.gov, 2008). In the Republic of Belarus, "traffic calming" is provided with generally forced (physical) speed limits by installation of humps.

The emergence and application of humps is connected with the significant increase in the accident rate in the second half of last century, which became in a number of the countries a national problem. Especially it concerned the Western European countries with dense population and features of a settlements design with narrow streets of historically developed building. Search of solutions led to requirements of sharp reduction in cars speeds (Department for Transport, 2010; Jones, Lyons, John, \& Palmer, 2005). In the beginning, there were attempts to implement it by installation of road signs with a speed limit. However, it didn't give special effect. In the different countries, violations of the high-speed mode was different, but the order of digits remained stable $-75-95 \%$ of drivers violated requirements of a speed limit.

Then began to look for and find ways of a forced speed limit. Different devices belong to the first method (psychological enforcement) (effect of narrowing or a curvature of a lane; effect of a rupture of a movement path, the becoming frequent flashing of a special marking; "the narrow gate"; noise bands, etc.). They create psychological need of a speed reduction at the driver (Räsänen, 2005; Department for Transport, 2010; Gattis, 2010).

Different devices which cause physical requirement of the speed reduction to the threat of the controllability loss or the accident (ring intersections with a small diameter of the central island belong to the second way; physical narrowing or curvature of a driving lane; sharp physical curvature of the road ("zigzag"); the crosswalks raised over the carriageway; cross deepenings and the acting obstacles (humps) of the most various designs and the sizes. The last devices were the cheapest, effective, not demanding control and gained the greatest distribution.

All new and new modifications of humps were developed. The process of their interaction with the car was investigated. Their efficiency in increase in traffic safety was declared (TrafficLogix, 2017). However it was soon established that application of humps, except positive impact on traffic safety has also a number of negative impacts in the field of economy, ecology and sociology (BBC News, 2003; Fazzalaro, 2006). The application of humps conflicts with fundamental problems of traffic improvement of quality and decrease in cost value of transport service which are based on all main properties of traffic - safety, profitability, environmental friendliness and a sociological, and not just on safety. Without having an opportunity in number to evaluate a ratio of the main properties, we began to limit application of humps in standard situations.

In particular, in many countries (with different variations) installation of humps is prohibited on country roads, on city streets with the heavy and moderate traffic, on roads with the passenger 
transport traffic, on streets with the cargo transport traffic, etc. Gradually the scope of humps is narrowed and limited to streets of the apartment block, domestic territories, areas of schools, etc. (Robinson, 2003; Preston, 2006).

\section{Research methods}

In city conditions such categories of traffic participants as pedestrians and cyclists are exposed to the greatest danger (about $50 \%$ of accidents in city conditions with victims).

It is also necessary to note that such cause of accidents in city conditions as:

- speeding makes from 8 to $16 \%$ of accidents of total annually;

- violation of thoroughfare of the crosswalk - from 21 to $25 \%$;

- an pedestrians come out from behind the parked vehicle (V) - from 2 to $4 \%$.

And, annually from 13 to $20 \%$ of accidents with victims in city conditions happen on unregulated crosswalks, about 5\% - in residential zones (in domestic territories and local drives).

Some physical impact measures are applied within approach on traffic calming:

- humps of different types (humps and bumps) and the raised sites of the carriageway;

- dividing strips, safety islands, narrowing's of the carriageway, side reserve strips;

- zigzags and cycles of small radius;

- portal designs;

- combination of speed control measures.

Humps, dividing strips, safety islands and narrowing of the carriageway are widely applied for the purpose of the speed reduction (Fig. 1). Bushes or trees ranks can be established on central dividing and side reserve strips, safety islands various protection.

Figure 1: The arrangement of the crosswalk with application of a safety island and a hump (a) - Golubev St., 28, Minsk, Belarus; b) - the avenue of the Zvyazda newspaper, 56, Minsk, Belarus)

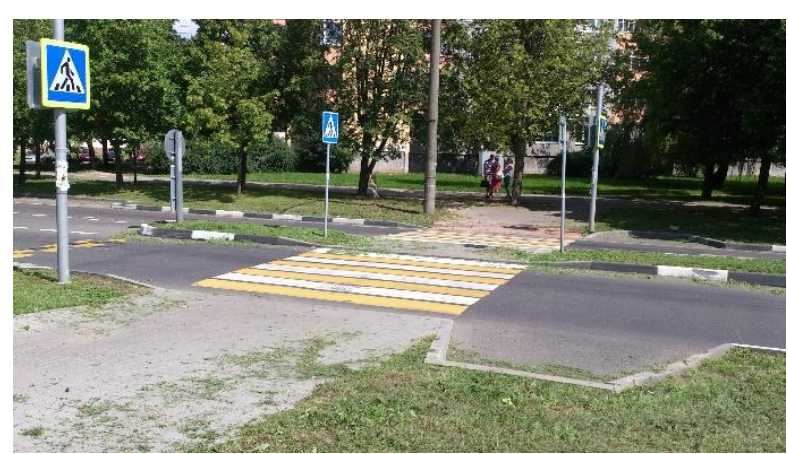

a)

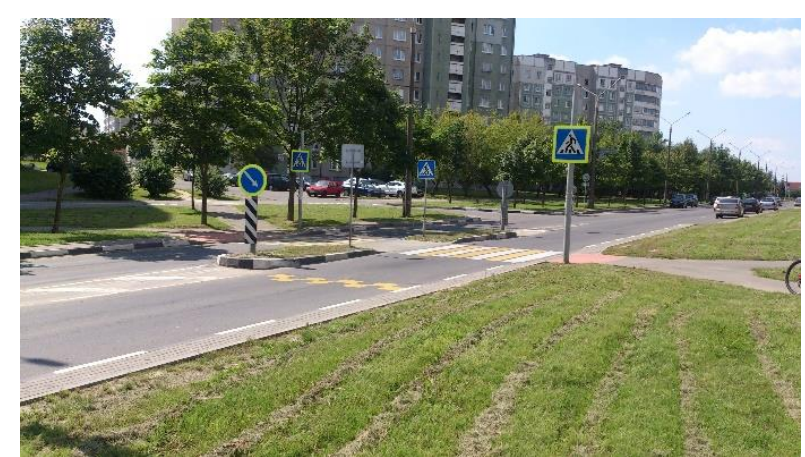

b)

"Zigzags" and cycles of small radius (Fig. 2) are applied on roads with the allowed traffic speed to $60 \mathrm{~km} / \mathrm{h}$. The purpose of their application is visual interruption of direct through traffic prospect.

Portal designs. Portal designs (Fig. 3) make an impression of entrance to a zone with other traffic conditions which demand change of transport behavior (the traffic speed reduction, the increase in attentiveness to traffic conditions). 
Figure 2: The application of a zigzag on the street section

(a - Nekrasov St., 112, Minsk, Belarus; b - Melezha St., Minsk, Belarus)

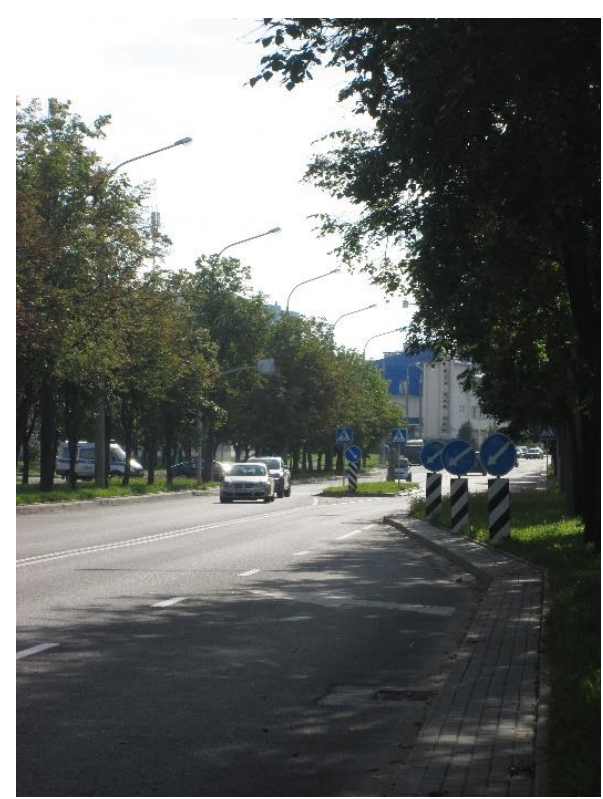

a)

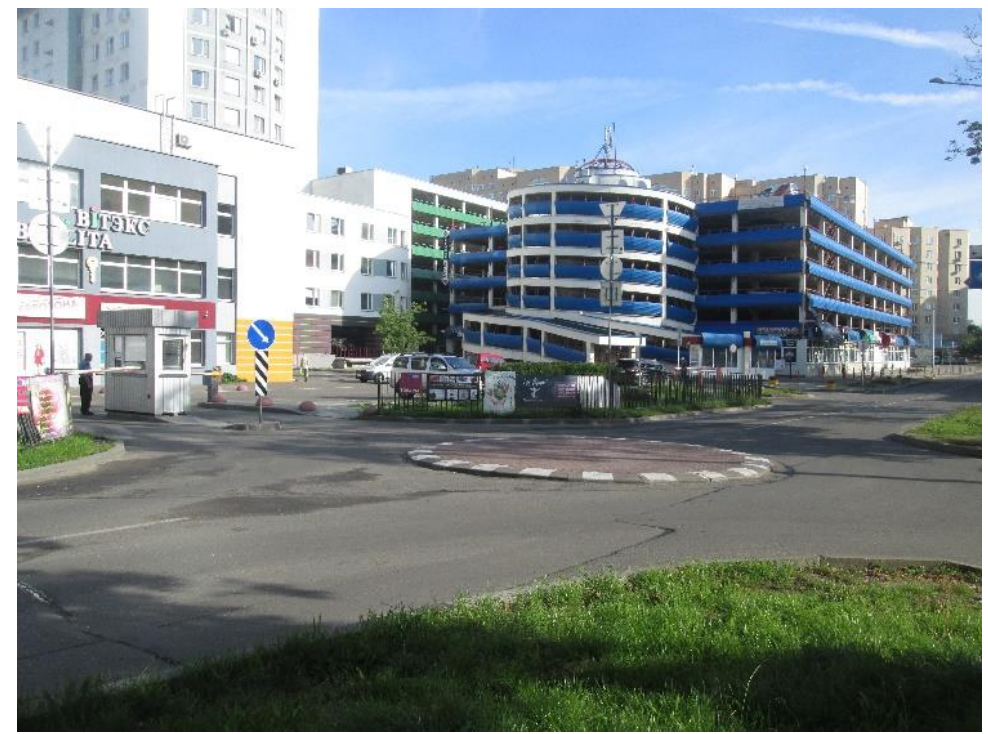

b)

Figure 3: The application of a portal design (Orlovskaya St., Minsk, Belarus)

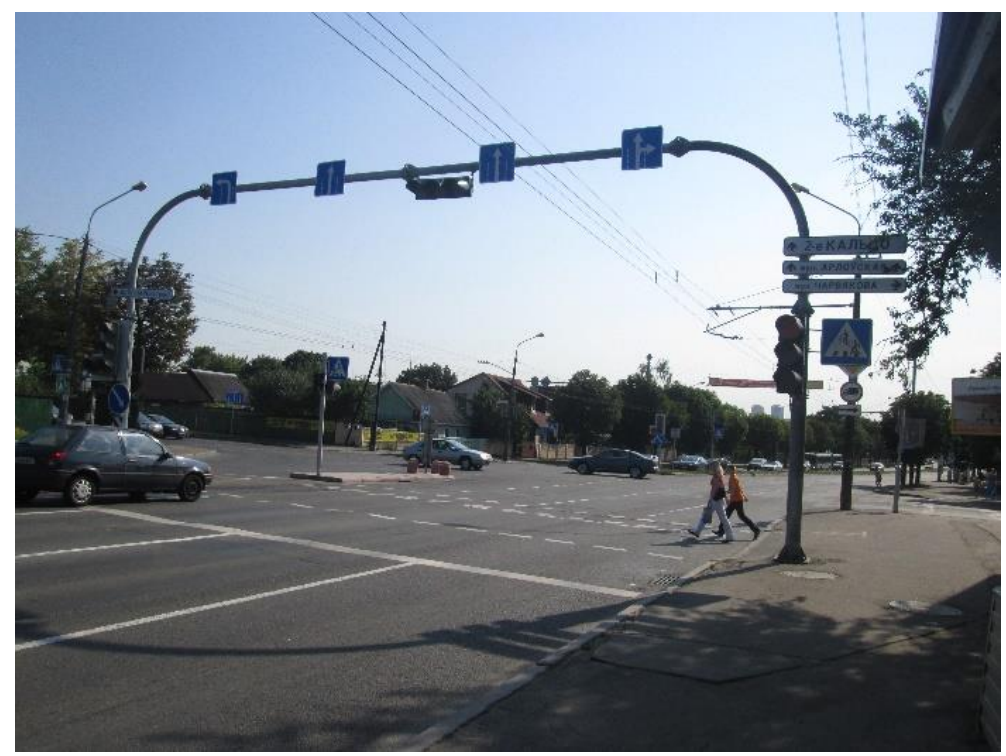

The zone combination (Fig. 4) (the combination of various measures for speed regulation in borders of a city area) consists of the following components:

- a narrowing of the carriageway to one strip and also the raised crosswalk;

- a narrowing of the carriageway to one strip and also a hump;

- a zigzag with narrowing to one strip;

- a zigzag with the raised crosswalk;

- a zigzag with narrowing and the device of a hump;

- a interruption of direct prospect of the transit. 
Figure 4: The combined narrowing's application of the carriageway, the humps and LED lamps set at the hump base

(a) - Ya. Chechot St., 21, Minsk, Belarus; b) - Ya. Chechot St., 20, Minsk, Belarus)

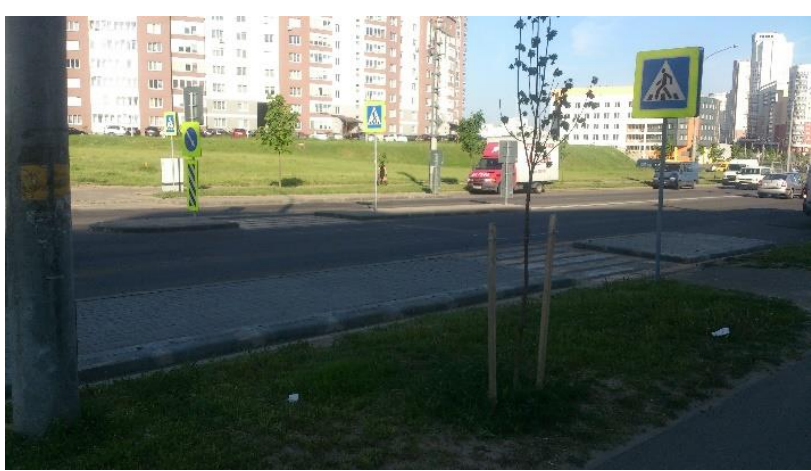

a)

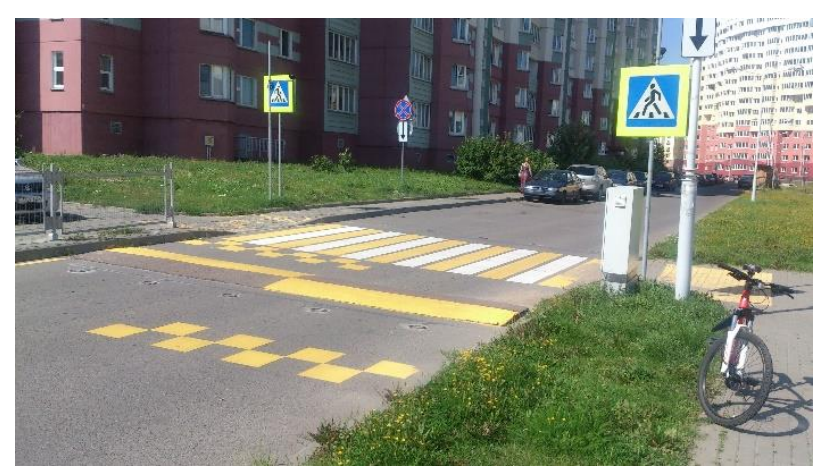

b)

It should be noted that practically all from the provided decisions have been offered and proved by specialists of Research traffic center of the BNTU branch "Research Part". The criterion of applicability of these decisions is the minimum of total losses in traffic.

\section{Research results}

Main parameters of humps are calculated on ensuring vehicles driving within a certain speed with insignificant inconveniences (approximately, $30 \mathrm{~km} / \mathrm{h}$ ) (Kapski, 2015). In tab. 1 results of a research of humps influence in a zone of crosswalks at choice of the traffic speed in various pieces of sites (30 meters before the hump, in the hump, 30 meters after the hump) are showed (Minsk, Belarus). For each piece were taken not less than 30 measurements of an instantaneous speed.

\begin{tabular}{|c|c|c|c|c|}
\hline \multirow[t]{2}{*}{ The installation site } & \multicolumn{3}{|c|}{ an instantaneous speed $V, \mathrm{~km} / \mathrm{h}$} & \multirow{2}{*}{$\begin{array}{l}\text { an authorized } \\
\text { speed } V, \mathrm{~km} / \mathrm{h}\end{array}$} \\
\hline & $\begin{array}{l}30 \text { meters } \\
\text { before }\end{array}$ & $\begin{array}{l}\text { in the } \\
\text { hump }\end{array}$ & $\begin{array}{c}30 \text { meters } \\
\text { after }\end{array}$ & \\
\hline 1 & 2 & 3 & 4 & 5 \\
\hline \multicolumn{5}{|l|}{ 2-band streets } \\
\hline Belorusskaya St., 15 & 27 & 12 & 25 & 30 \\
\hline 2-Velosipedny lane, 30/2 & 32 & 15 & 34 & 40 \\
\hline Yakubov St., 48/1 & 29 & 19 & 34 & 40 \\
\hline Chervyakov St., 20 & 28 & 15 & 30 & 40 \\
\hline Internatsionalnaya St., 25 & 32 & 15 & 33 & 40 \\
\hline Average speed & 30 & 15 & 31 & \\
\hline \multicolumn{5}{|l|}{ 4-band streets } \\
\hline Ulyanovskaya St., 31 & 39 & 17 & 36 & 40 \\
\hline Karastoyanova St., 21 & 34 & 16 & 31 & 40 \\
\hline Kiselyov St., 4 & 31 & 15 & 35 & 40 \\
\hline Promyshlenny Lane, 12 & 37 & 16 & 35 & 40 \\
\hline Angarskaya St., 12/1 & 35 & 16 & 39 & 40 \\
\hline Average speed & 35 & 16 & 35 & \\
\hline \multicolumn{5}{|c|}{ 4th band streets with a wide dividing strip (more than $10 \mathrm{~m}$ ) (boulevards) } \\
\hline Tukhachevsky St. - Zhilunovich St. & 36 & 13 & 40 & 40 \\
\hline Komsomolskaya St. - K. Marx St. & 27 & 14 & 28 & 30 \\
\hline Shevchenko Blvd., 18 & 31 & 17 & 35 & 40 \\
\hline
\end{tabular}




\begin{tabular}{|c|c|c|c|c|}
\hline 1 & 2 & 3 & 4 & $\mathbf{5}$ \\
\hline Kuleshov St., 2 & 27 & 18 & 29 & 40 \\
\hline Centralnaya St., 1 & 35 & 25 & 39 & 40 \\
\hline Average speed & 31 & 17 & 34 & \\
\hline \multicolumn{5}{|l|}{ 6-band streets } \\
\hline Plekhanov St., 72 & 26 & 14 & 28 & 30 \\
\hline Gorodskoy Val St., 4 & 29 & 15 & 26 & 40 \\
\hline Yakubov St., 58 & 27 & 14 & 32 & 40 \\
\hline Selitsky St. - Elnitskaya St. & 39 & 14 & 38 & 40 \\
\hline Varvasheni St. - Altayskaya St. & 40 & 15 & 42 & 40 \\
\hline Average speed & 32 & 14 & 33 & \\
\hline
\end{tabular}

A traffic density and a size of a interval between cars have significant effect on the emergence of the conflicts in a zone of humps installations. In tab. 2 results of a research of traffic density, intervals and instantaneous speeds in installation sites of humps are showed.

\section{Table 2: Indicators of a traffic density, a spatial interval and a instantaneous speed in humps}

\begin{tabular}{lcc}
\multicolumn{1}{c}{ Indicators } & 30 meters before & in humps \\
\hline the average speed, $\mathrm{km} / \mathrm{h}$ & 33 & 18 \\
the studied interval between cars, $\mathrm{m}$ & 13 & 7 \\
the reference interval between cars, $\mathrm{m}$ & 20 & 15 \\
the studied traffic density, cars/km & 76.9 & 142.9 \\
the reference traffic density, cars $/ \mathrm{km}$ & 50.0 & 66.7
\end{tabular}

The reference site - a horizontal straight section of the street with two lanes $(3.75 \mathrm{~m})$ in both directions and distance of visibility in the direct direction not less than $800 \mathrm{~m}$.

According to the some information in the places with humps the accident rate with victims can decrease to $50 \%$, but the accident rate with material damage considerably increases. Some dates on the accident rate in installation sites of humps are shown in tab. 3. The analysis of the accident rate was carried out from 2010 for 2015.

\begin{tabular}{|c|c|c|c|}
\hline \multirow{3}{*}{ Installation site } & \multirow{3}{*}{ years } & \multicolumn{2}{|c|}{ Number of accidents } \\
\hline & & $\begin{array}{l}\text { before the hump } \\
\text { installation }\end{array}$ & $\begin{array}{l}\text { after the hump } \\
\text { installation }\end{array}$ \\
\hline & & $\begin{array}{l}\text { with victims / } \\
\text { without victims }\end{array}$ & $\begin{array}{l}\text { with victims / } \\
\text { without victims }\end{array}$ \\
\hline \multicolumn{4}{|l|}{ 2-band streets } \\
\hline Belorusskaya St., 15 & 2004 & - & $0 / 4$ \\
\hline 2-Velosipedny lane, 30/2 & 2007 & - & $0 / 4$ \\
\hline Yakubov St., 48/1 & 2009 & - & $3 / 3$ \\
\hline Chervyakov St., 20 & 2011 & $0 / 0$ & $2 / 4$ \\
\hline Internatsionalnaya St., 25 & 2013 & $0 / 2$ & $0 / 2$ \\
\hline \multicolumn{4}{|l|}{ 4-band streets } \\
\hline Ulyanovskaya St., 31 & 2010 & - & $1 / 4$ \\
\hline Karastoyanova St., 21 & 2010 & $0 / 1$ & $3 / 1$ \\
\hline Kiselyov St., 4 & 2011 & $0 / 0$ & $1 / 2$ \\
\hline Promyshlenny Lane, 12 & 2011 & $0 / 2$ & $0 / 2$ \\
\hline Angarskaya St., 12/1 & 2014 & $1 / 0$ & $0 / 0$ \\
\hline
\end{tabular}




\begin{tabular}{lccc}
\hline 4th band streets with a wide dividing strip (more than $\mathbf{1 0}$ m) & (boulevards) & \\
\hline Tukhachevsky St. - Zhilunovich St. & 2011 & $0 / 8$ & $0 / 3$ \\
Komsomolskaya St. - K. Marx St. & 2010 & - & $3 / 13$ \\
Shevchenko Blvd., 18 & 2012 & $0 / 0$ & $1 / 0$ \\
Kuleshov St., 2 & 2013 & $2 / 3$ & $0 / 0$ \\
Centralnaya St., 1 & 2014 & $1 / 3$ & $0 / 0$ \\
\hline 6-band streets & & & $2 / 4$ \\
\hline Plekhanov St., 72 & 2004 & - & $1 / 3$ \\
Gorodskoy Val St., 4 & 2007 & - & $0 / 1$ \\
Yakubov St., 58 & 2015 & $1 / 0$ & $1 / 32$ \\
Selitsky St. - Elnitskaya St. & 2011 & $3 / 9$ & $0 / 1$ \\
Varvasheni St. - Altayskaya St. & 2014 & $0 / 1$ & \\
\hline
\end{tabular}

It is also necessary to consider negative impacts in the field of economy, ecology and sociology for effective application of humps, except decrease in the accident rate (Kapski D.V., 2015). The complex analysis by criterion of "loss" of a standard object is submitted in the Tab. 4.

Table 4: Results of comparison of losses in traffic by decisions versions

\begin{tabular}{lcccc}
\multicolumn{1}{c}{ Name of 'loses' } & Index & Parameter & $\begin{array}{c}\text { Real scheme of the } \\
\text { traffic } \\
\text { organization } \\
\text { (hump) }\end{array}$ & $\begin{array}{c}\text { offered scheme of } \\
\text { the traffic } \\
\text { organization (a } \\
\text { traffic light object) }\end{array}$ \\
\hline Emergency losses & $\mathrm{Pa}$ & $(* 103)$ dollars/year & 24.8 & 4.4 \\
Ecological losses & $\mathrm{Pecl}$ & $(* 103)$ dollars/year & 32.5 & 21.4 \\
Economic losses & $\mathrm{Pecn}$ & $(* 103)$ dollars/year & 85.1 & 66.2 \\
\hline Total losses & $\Sigma$ & $(* 103)$ dollars/year & 142.4 & 92.0 \\
\hline
\end{tabular}

\section{Discussion of the results}

The humps application began to be restricted on country roads, city streets with heavy and moderate traffic, on streets and roads with cargo traffic and route passenger traffic as a result of experience of the long humps using as in our country and abroad. It is set that in a national context humps did not bring the expected notable lowering of breakdown susceptibility (Preston, P. A, 2006). Gradually the scope of humps is restricted to streets of the apartment block, the domestic territories, the adjacent territories of large objects of inclination.

The hump reduces abnormal losses by lowering of number of accidents with victims with a simultaneous growth of accidents with the material damage and sharp increase in economic and ecological losses a little. It does application of humps in comparison with other measures (improving of visibility and conditions of maneuvering, accurate designation of a zone of the crosswalk, restriction of speed with an automatic video inspection, the organization of the crosswalk like "Choice", the organization of the adjustable crosswalk with the alerting device, etc.) functionally inadequate, economically both ecologically wasteful and socially destructive. Therefore installation of a hump is a last resort of impact on all participants of traffic including law-abiding drivers and passengers.

The hump in case of the appropriate reasons can be set:

- in residential zones and the domestic territories equated to them where motion speed is limited by $20 \mathrm{~km} / \mathrm{h}$ and less by law;

- as an exception, for example, during steep descent before schools - on double-sideband streets of local value with intensity of movement no more than 120 cars/h totally in both directions.

The breakdown center at the specific crosswalk, depending on the specific reasons of accidents, can be liquidated by improving of visibility, informativeness, the device of safety islands, the installation of the functional pedestrian barriers and other more effective methods of the traffic organization. It is necessary to observe operating standards which, for example, forbid nonadjustable crosswalks on the multiband, especially loaded trunk streets, etc. 


\section{Conclusions}

There is a need for effective complex measures for speed control at the local, state, regional and international levels.

All actions have to be planned and be carried out within the concept of speed reduction. Creation of safe and comfortable conditions for their participants to keep lives of people (Vision, 2017; Whitelegg, 2006; Vision Zero Oregon, 2016) has to be a main goal of introduction of new approaches in the traffic organization.

It is offered, any decision on the traffic organization will estimate by criterion of minimization of total losses in traffic. For this purpose the complex an efficiency assessment technique developed in our country. Offers have found reflection in the different official traffic documents.

\section{Appendix A. Supplementary material}

Supplementary data associated with this article can be found, in the online version, at https://jsdtl.sciview.net

\section{Funding}

The authors received no direct funding for this research.

\section{Citation information}

Kapski, D., \& Korzhova, A. (2017). The analysis of various measures of the speed control of the traffic in the cities and settlements of the Republic of Belarus. Journal of Sustainable Development of Transport and Logistics, 2(2), 26-34. doi:10.14254/jsdtl.2017.2-2.2.

\section{References}

BBC News. (2003). Road humps may go. 3 September, 2003. Retrieved January 26, 2004 from http://news.bbc.co.uk/2/hi/uk_news/england/derbyshire/3077304.stm.

Department for Transport. (2010). Interim Evaluation of the Implementation of 20 mph Speed Limits in Portsmouth: Final Report. Retrieved April, 12, 2016 from http://www.dft.gov.uk/ $\mathrm{pgr} /$ roadsafety/speedmanagement/20mphPortsmouth/pdf/20mphzoneresearch.pdf.

Fazzalaro, J. J. (2006). Speed bumps and speed humps. Connecticut General Assembly, Office of Legislative Research.

Gattis, J. L. (2010). Guide for the geometric design of driveways (Vol. 659). Transportation Research Board. $\quad$ Retrieved $\quad$ March $\quad 10, \quad 2017$ from http://onlinepubs.trb.org/onlinepubs/nchrp/nchrp_rpt_659.pdf.

Jaeger, R. R. (2008). Traffic calming - speed humps effect. Des Plaines Fire Department, Illinois. Retrieved October 14, 2016 from http://www.usfa.dhs.gov/pdf/efop/efo42774.pdf.

Jones, S. J., Lyons, R. A., John, A., \& Palmer, S. R. (2005). Traffic calming policy can reduce inequalities in child pedestrian injuries: database study. Injury Prevention, 11(3), 152-156.

Kapski, D. V., Korzhova, A.V., \& Skirkovsky S.V. (2015). Transport in planning cities. Abstract of lectures. Minsk, Belarus: BNTU.

Maine.gov (2008). Implementing Maine's Sensible Transportation Policy Act through Coordinated Transportation and Land Use Planning. Handbook for Local and Inter-Community Transportation Planning in Maine. Retrieved June 25, 2016 from http://www.maine.gov/mdot/planningdocuments/stpa/handbook/SensibleTransportation09 2908.pdf.

Preston, P. (2006). A surge of the humps. Sleeping policemen sprout with the daffodils. But it's more to do with budgets than braking. The Guardian. Retrieved March 27, 2006. 
Preston, P. (2006). A surge of the humps. Sleeping policemen sprout with the daffodils. But it's more to do with budgets than braking. The Guardian. Retrieved March 27, 2006 from http://www.guardian.co.uk/commentisfree/2006/mar/27/comment.transport..

Räsänen, M. (2005). Effects of a rumble strip barrier line on lane keeping in a curve. Accident Analysis \& Prevention, 37(3), 575-581.

Robinson, G. (2003). Speed Bumps and Humps. Gotham Gazette: The Place for NYC Politics and policy. Retrieved May 05, 2003.

TrafficLogix. (2017). Traffic Calming Statistics. Retrieved March 10, 2017 from http://www.trafficlogix.com/statistics.asp.

Vision Zero Oregon. (2016). Vision Zero Oregon Neighbors Working for Safer Streets. Retrieved March 19, 2017 from http://www.visionzerooregon.org/the-project/.

Vision Zero. (2017). Vision Zero Initiative. Traffic safety by Sweden. Retrieved March 19, 2017 from http://www.visionzeroinitiative.com/ru/concept/.

Whitelegg, J., \& Haq, G. (2006). Vision Zero: Adopting a target of zero for road traffic fatalities and serious injuries. Stockholm, Sweden: Stockholm Environment Institute.

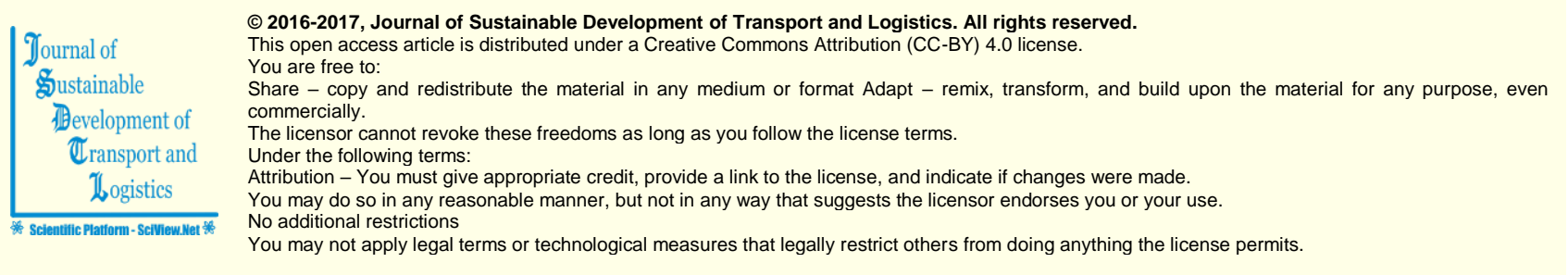

Journal of Sustainable Development of Transport and Logistics (ISSN: 2520-2979) is published by Scientific Publishing House "CSR", Poland, EU and Scientific Publishing House "SciView", Poland, EU

Publishing with JSDTL ensures:

- Immediate, universal access to your article on publication

- High visibility and discoverability via the JSDTL website

- Rapid publication

- Guaranteed legacy preservation of your article

- Discounts and waivers for authors in developing regions

Submit your manuscript to a JSDTL at http://jsdtl.sciview.net/ or submit.jsdtl@sciview.net 